$D a$, we never liked you anyway,

So kneel, we're Americans and crazy.

But it's still early, there's much

Jeff Mock must do, promises

And threats to make, opponents to compromise,

Enemies to befriend. He'll do just

What it takes, he'll take just

What he can. Power, he says. He speaks

Softly, but carries a big megaphone.

\title{
Epithalamion for Sarah and Tony
}

Her veil, his tie-

They do, and undo

What has not been

Undone. Deer pause

Below their window,

On the sill sparrows

Alight, the wilds

Uncoil and listen in.

Even the mountain

Leans all night down

To discover their

Discovery.

All night it listens

For the wind lifting

The sheets, the lake's

Low murmur lapping

The bed. All night

The mountain leans 
Closer and presses

An ear to every

Sound. The mountain

Leans closer, down,

And down, and soon

Levels, becomes

The bed they lie in.

And they become

The mountain, rising

Above the mountain

That listens in. 